\title{
TARIFA AFRICAN FILM FESTIVAL AND THE RE-REPRESENTATION OF AFRICA
}

Federico Olivieri

SOAS - University of London ${ }^{1}$

\section{INTRODUCTION}

In our contemporary interconnected world, much of the information and knowledge communicated is through audiovisual works which constitute representations of the external reality. In these processes, Africa has oftentimes been described by European and Western images in which several misrepresentations have obscured the heterogeneity of the continent. African cinema is considered one of the main truly African audiovisual representations of a real perception of this misunderstood reality. However, when it comes to watching and learning about African cinema in our Western societies, apart from the relatively few academic studies on African media and audiovisual production, one mainly has access to these images through African film exhibition events such as African film or video showcases or during international film festivals in which African cinema is programmed. Among the latter, African film festivals have seen an important proliferation, especially in Europe and America throughout recent decades (Anthony, 2005; Ecrans d'Afrique, 1994).

Amid this "boom" of African film events in Europe, the Festival de Cine Africano de Tarifa (FCAT - Tarifa African Film Festival), in Spain, constitutes an interesting case through which the meaning of "Africa" vis-à-vis our contemporary Western media culture can be explored. In this paper, I look at the birth, evolution and above all, the characteristics of this specialised film festival in order to explore how Africa is conceptualised and represented in Spain.

The FCAT constitutes a growing cultural event that has opened up new spaces of knowing and understanding Africa in Spain. At the same time, in eight years, this film event has augmented its recognition and influence in its cultural sector: that of African film festivals and contemporary African cinema industries. The FCAT presents a singularity due to its location, since the geographical proximity of Tarifa to Africa makes it the closest European African film festival to the African continent. This has allowed Tarifa not only to stop representing a border town of geopolitical and cultural separation between Africa and Europe, but also to promote interculturalism as a dialogue-based socio-cultural model for our con-

1 This article is mainly based on a Master thesis, supervised by Dr. Lindiwe Dovey, completed and submitted by the author at the School of Oriental and African Studies (University of London) on $15^{\text {th }}$ September 2009. The author is currently working as the AECID cultural cooperation assistant at the Embassy of Spain in Nairobi (Kenya). 
temporary interconnected societies. In this sense, the FCAT represents in Tarifa a contemporary and innovative cultural bridge, in which African films become the encounters and links between the two continents. At the same time, the FCAT also constitutes an event that has been able to influence the perspectives and actual policies of Spanish international cooperation programmes, moving them towards the support of African cinema. For all these reasons, analysing the characteristics of this film festival, together with the representations of Africa on Spanish mainstream media, will not only show the meaning of African cinema for a more realistic image of Africa, but will principally argue the relevance of African film festivals as strategic systems for the knowledge of Africa and the development of its African cultural industries.

This small study can be observed as an interdisciplinary work, framed within the intersections of different fields of study. These cover notions from theoretical backgrounds of media studies, African film studies and, above all, from the relatively recent discipline of film festival studies. The latter represents in fact the main discipline in which I shall situate the conclusions drawn from the analysis of my case study: the FCAT or Tarifa African Film Festival.

\section{THE FCAT: EVOLUTION, CHARACTERISTICS AND INTERCULTURALISM IN SPAIN}

The FCAT is a specialised film event that has recently celebrated its eighth edition in Tarifa (11-19 June 2011), the southernmost town of continental Europe, on the Spanish coast facing Morocco. This festival was founded in 2004 with the intention of creating a different cultural space for the exhibition of African films, conceived as a tool to broaden the knowledge about and the dialogue with those who live on the lands on the other side of the Strait of Gibraltar. In fact, apart from its famous windy long sandy beaches and sailing sports tourism, Tarifa is mostly known among Spanish people for being a border city from where much tragic news about African illegal immigration has been reported. In this sense, this Andalusian town has for many mainly represented a point of separation, a frontier between Spain and Morocco or Europe and Africa. These two continents are in fact only $14 \mathrm{~km}$ apart from one another in this geographical area, making Tarifa one of the closest (continental) European towns to the African continent.

Since its birth, the promotional descriptions for Tarifa's African film event have highlighted a new image for this Spanish town as a "transit place and dialogue bridge between people" (MCAT, 2004: 2). The FCAT has thus been defined as a symbolic cultural bridge between the two continents, embodying also a space in which African films are used to generate intercultural dialogue and encounters. Just as internationally acclaimed Guinean filmmaker Mama Keita commented during his second visit to the festival in May 2009: "the FCAT is a mirror facing Africa" (Keita, 2009). Similarly, renowned Malian-Mauritanian filmmaker Abderrahmane Sissako insisted on the importance of an African festival like FCAT, hailing it as 'a bridge that politicians never make' (Sissako, 2009).

In the general panorama of Spanish film events, only in the city of Barcelona was there already a precedent event of this kind, the Mostra de Cinema Africà de Barcelona, whose cultural association, L'Ull Anònim, was the first to bring African cinema to Spanish audiences. The Catalan showcase started in 1996 and celebrated its fifteenth edition during 5-11 November 2010. This Barcelona event has always been a 'muestra' of African and African-American diasporic cinema, rather than a festival that gives prizes and awards. 
The FCAT was born from a non-profit privately driven Spanish organisation named AlTarab, which Mane Cisneros Manrique - founder and director of this film event — created with a small group of collaborators in 2004. The FCAT was initially called Muestra de Cine Africano de Tarifa- MCAT (Tarifa African Cinema Showcase), since it was merely focused on the thematic exhibition and discussion of African films. Analysed in numerical terms, the FCAT has strongly grown in its eight years of existence. Its large programme (140 titles were screened in its 2011 edition) and the $€ 46,500$ given by the festival in 2011 to African film production through nine different awards, have made the FCAT become one of the reference points for African film exhibition and recognition in Europe (Dovey, 2010: 55). This growth was mainly possible thanks to the economic and logistic support of different governmental departments, agencies and ministries of Andalusia and Spain, ${ }^{2}$ as well as private sponsors from different sectors ${ }^{3}$. Particularly through its engagements with the Agencia Española de Cooperación Internacional para el Desarrollo (AECID — the Spanish Agency of International Cooperation for Development- an institution housed within the Spanish Ministry of Foreign Affairs) and Casa África (the Canary Islands-based Spanish intergovernmental institution for the promotion of mutual relationships and knowledge between Spain and Africa), the FCAT could augment its views and become an actual award-giving festival in 2006/07. With these new possibilities, the FCAT initiated seven film awards, which it granted to African cinema as a means to generate a real support for the African film industry. An important element that can be pointed to as the confirmation of this enriching partnership between the FCAT and the statutory bodies, is the mention of Tarifa's event in the Plan África 2006-2008 (the Spanish Foreign Affairs Ministry strategic plan for the Socialist government's diplomatic and international actions between Spain and Sub-Saharan Africa) and in the following Plan África 2009-2012 (MAEC, 2009: 86). This influential inclusion of the FCAT in these governmental action plans can be considered an relevant factor that ensured the growth and maturity not only of the event, but also of Al-Tarab as a committed active cultural organisation for the fulfilment of Spanish policies for cultural cooperation with Africa.

At the same time, it is important to note that Tarifa's cultural work can also be linked with the wider international programme of the Alliance of Civilisations. This international initiative, conceived by the Spanish government of José Luís Rodriguez Zapatero together with Turkey at the $59^{\text {th }}$ General Assembly of the United Nations in 2005, seeks to "improve understanding and cooperative relations among nations and peoples across cultures and religions" (Alliance of Civilization, 2009). This international mission involves thus the promotion of international, intercultural and inter-faith dialogue through "supporting a range of projects and initiatives aimed at building bridges among a diversity of cultures and communities" (Alliance of Civilizations, 2009). It is within the frame of this new global intercultural political discourse, and in particular the Spanish government's support of civil society's

2 The FCAT has mainly been possible, among other collaborating organisations, thanks to the following sponsoring entities (names in Spanish): AECID - Ministerio de Asuntos Exteriores y de Cooperación, Casa África, Consejería de Cultura - Junta de Andalucía, Ministerio de Cultura, Fundación Dos Orillas, Fundación Provincial de Cultura - Diputación de Cádiz, Excmo. Ayuntamiento de Tarifa, Casa Árabe, Centro Andaluz de la Fotografía, Fundación Tres Culturas.

3 The main private sponsors that financially and logistically contributed towards the celebration of the $8^{\text {th }}$ FCAT are (listed in order of economical support and relevance): Fundación Caja Sol, Al-Yazeera Documentaries, TV5-Monde, FRS - Ferries Rápidos del Sur, Turkish Airlines, Hotel Misiana-Tarifa, and many other national and local partners (see full details in www.fcat.es $>8^{\circ}$ FCAT'11 > "Patrocinadores"). 
(inter)cultural projects, that the FCAT is best analysed. The FCAT has benefitted from this institutional Spanish predisposition towards interculturalism and has flourished into an independent organisation which promotes, through the use of African cinema, what the Plan África encourages: "bilateral cultural exchanges" between African countries and Spain and the rapprochement of "a contemporary and plural image of the cultural diversity that characterises African societies" (MAEC, 2006: 97).

\section{AFRICAN CINEMA DIFFUSION AND PROFESSIONAL OPPORTUNITIES}

The FCAT and its association Al-Tarab have always demonstrated a commitment as far as the industry of African cinema is concerned. The raison d'être of this film festival has not merely been showing (and awarding) African films, producing what Diawara critiqued as the "ghettoization" of African cinema at African film festivals (Diawara, 1994: 386). Rather, the FCAT has always shown a motivation to create more professional opportunities for African cinema and its creators, thus trying to fight against the problems that this sector faces in the global film industry. In order to try to diminish the difficulties of African filmmakers' "battle for resources, production, distribution and exhibition" for their films (Andrade-Watkins, 2002: 2), Al-Tarab has increasingly promoted and organised different specialised initiatives, both inside and outside the FCAT. In the exhibition realm, the FCAT provides Spanish subtitles for all selected African films in order to support Al-Tarab and Casa África's project Cinenómada (nomadic cinema), through which these films are circulated through numerous Spanish and international towns, cultural centres and universities for non-commercial exhibition. In this sense, the FCAT is not a discrete annual event, but a year-round dedicated project. At the same time, the FCAT has given a boost to the commercial distribution of African films in Spain, both by facilitating the commercial acquisition of its winning titles in a special DVD pack produced by the media company for independent cinema Cameo Media S.L., and also by organising professional meetings between African filmmakers and Spanish distribution companies. During latest $8^{\text {th }}$ FCAT the collaboration between the festival and Africafilm.tv, a new internet-based platform for on-line African cinema distribution, was also announced as a way to promote an alternative method in currently changing world cinema distribution patters (Africanews.it, 2011).

Enhancing distribution opportunities is not the only activity addressed to the professional sphere during the FCAT. In fact, in order to become a truly specialised film festival in which African cinema can find fulfilment for, using Bangré's descriptions, both his "cultural and economic expectations" (Bangré, 1996: 158), the FCAT created a new specialised department called "FCAT Espacio Profesional" (FCAT Professional Space), which aim is "to create collaboration networks and new common spaces of understanding for a better penetration and reception of African cinema and cultures in Spain" 4 (FCAT, 2011). In this innovative space, inaugurated in 2009, the FCAT now celebrates its annual Spanish-African co-production forum called "África Produce", together with a series of professional meetings for the reinforcement of African film industries and its new "African cinema history seminar", one of the first Spanish language academic-oriented courses of African film studies ever registered in Spain (FCAT, 2011).

4 Translation from the original Spanish version into English made by the author.

Quaderns, 7 (2011), pp. 79-92 


\section{RE-PRESENTING AFRICA AND THE FCAT: WESTERN MEDIA DISCOURSES AND THE FESTIVAL}

When one has no direct experience of a place, person or thing, the media becomes one of the major sources of information about that 'other' which one knows little or nothing about. Therefore, the descriptions and visualizations that any means of social communication makes available to us constitute a representation, on which we often rely to construct an image about what we do not personally and/or intimately know. In this sense, just as Helsby argues, "the media do provide us with a paradigm of how to view the mediated world" (Helsby, 2005: 6). In this process, these media messages can also reinforce our beliefs and knowledge about reality, especially when they imply a repetition of certain images - in other words, they can create stereotypes.

When it comes to analysing the ways in which Africa and Africans have been represented by Western literature and mainstream national or international media, it can be observed that several misrepresentations have been associated with the continent and its people. This is something that the award-winning Kenyan author Binyavanga Wainaina masterly condenses in his satirical advice on "How to Write about Africa":

In your text, treat Africa as if it were one country. It is hot and dusty with rolling grasslands and huge herds of animals and tall, thin people who are starving. Or it is hot and steamy with very short people who eat primates. Don't get bogged down with precise descriptions. Africa is big: fifty-four countries, 900 million people who are too busy starving and dying and warring and emigrating to read your book. The continent is full of deserts, jungles, highlands, savannahs and many other things, but your reader doesn't care about all that, so keep your descriptions romantic and evocative and unparticular (Wainaina, 2005: 92).

Parallel to this literary perception, in Western audiovisual media production Africa has often been portrayed as "primitive, uncivilised and in a permanent state of crisis" (Helsby, 2005: 13). This is the predominant image that the Western mass media still offer of this vast continent, which multiple and heterogeneous realities are constantly simplified and condensed into negative stereotypes and misrepresentations.

As far as the mainstream Spanish mass media is concerned, one can observe that Africa is also mainly described -and thus perceived by Spanish audiences- as a vast land of adventures, exoticism and constant catastrophes, which are mainly reported by Western news agencies (Sendín Gutiérrez, 2006: 38). At the same time, to the Spanish —who did not have a determinant colonial relationship with the continent ${ }^{5}$ - Africa constitutes what Sendín Gutiérrez defines as the "strange, unknown continent, not integrated into the mental map of the majority of Spanish who watch television, read the press or listen to the radio" (Sendín Gutiérrez, 2006: 37). In fact, Africa is absent from the most renowned Spanish daily journal El País's electronic edition. Here, among the subheadings of its international news section, it presents only the following areas of international interest: Latin America, Europe, United States, Near East and

5 Spain only had a few colonies and protectorates in Africa during the period of European imperialism of the end of $19^{\text {th }}$ and first half of $20^{\text {th }}$ centuries; they corresponded to the current territories of Equatorial Guinea, Northern Morocco and Western Sahara. 
Correspondents (El Pais.com, 2011). This omission demonstrates that, despite the geographical proximity with Spain, Africa represents a region of little interest for Spanish readers. In such a context of negative representations, simplifications or even disinformation of the African reality, it seems easy to understand how stereotypes about Africa and Africans can proliferate.

At the same time, even though it is true that research about the treatment of Africans in Spanish media is limited, it must be acknowledged that, over the past few years, there has been a proliferation of communication studies which deal with the wider theme of immigration in Spain, both from Africa and beyond (Sendín Gutiérrez, 2006: 41; Galán Fajardo, 2006; Vázquez Aguado, 1999). This is due to the fact that in the second half of the 1990s Spain started experiencing, for the first time in its modern history, an increase in immigration flows. In fact, in the period 1998-2003, the number of foreigners residing in Spain multiplied by four (Galán Fajardo, 2006: 3). Because of its geographical position, Spain so became a "frontier" to Europe for the immigrants coming from Africa, while for South American migrants Spain represents an attractive destination due to the sharing of a common language.

The media, as informant and mediator between daily reality and the citizens, elaborates news about such burning topics, while they are also transferred into mass media entertainment audiovisual products. Just as Galán Fajardo demonstrates in her study about the representation of immigrants in Spanish television fiction, these representations cause an effect of generalisation, favouring the emergence of pre-assumptions and stereotypes (Galán Fajardo, 2006). In this sense, most Spanish media studies indicate that the dominant tendency treats the immigrant group as part of a national "problem", thus creating a "negative image of the Other -the immigrant" (Sendín Gutiérrez, 2006: 41). At the same time, just as Vazquez Aguado argues, most of this information about immigration inadequately introduces contextualised analyses of the reasons for migration, enhancing superficial and negative images of the immigrant. This means that the Spanish tend to relate immigration to notions of "invasion, conflict, threat and trouble" (Vazquez Aguado, 1999: 60).

Just as Thackway states, "today's representations of Africa [describe the continent] as a site of famine, poverty, disease and war, or, in other words, as 'Other' to the 'economically developed', safe West" (Thackway, 2003: 36). The African is then also observed as that other, in contrast to the white European, who risks her or his life to migrate to Europe, in search of a better life outside her or his inhospitable African motherland. In this context, the African is mainly portrayed by media in a "subordinated role... [as] a passive being [...], unable to do anything without the Western direction." (Sedín Gutiérrez, 2006: 41). In much of the media, Africans are thus merely described, photographed or filmed in news which lack of detailed contextualisation (Vázquez Aguado, 1999:60). In this way, Western cultural products eliminate the possibility of an African voice, producing a false representation of this continent and its people. In other words, Africa is misrepresented in Spanish and Western media, a fact that still promotes a Western-centric discourse (understood in the Faucauldian way) far from any intercultural praxis.

\section{ANALYSING REPRESENTATION(S) OF AFRICA AT THE FCAT}

The lack of African voices in Spanish media generates a partial, negative and simplistic conception of Africa and of its socio-cultural variety. In this sense, Tanzanian film-maker and academic Martin Mhando's observations about the role of the African film festival and this situation of unbalanced knowledge about Africa are clarifying: 
African film festivals are now one of the major education systems that are employed to understand Africa. They are like an acknowledgement of the failure of media sources at communicating what Africa means. When we see African film festivals outside of Africa, it demonstrates that a community has identified a need of knowing Africa better. [...] This is a moment of an acceptance of a need and the fulfilment of the need, and also the acceptance of the power of image in communicating knowledge (Mhando, 2009).

It can be argued that the FCAT clearly represents this need in Spanish society, as well as the acknowledgement of such failure of Spanish media in portraying Africa properly. The event also testifies that Al-Tarab, as a civil society's organisation, recognised this imbalance and saw in African cinema the truly African voice(s) or perspective to counteract this situation. With its wide and diverse African cinema programme, the FCAT offers to its physical and mediated audience a more varied and realistic representation of this misunderstood continent. With exactly 140 programmed films at its $8^{\text {th }}$ edition, the FCAT constitutes the biggest African film exhibition space ever seen in Spain. Therefore, it also constitutes the biggest (film) forum in which truly African messages can be received in a unique space where a new (mediated) dialogue with Africa can be established. In this sense, in order to understand what distinguishes this realistic representation of Africa in a cultural event like the FCAT, it is important to analyse the elements that help constructing such image.

Firstly by looking at its cultural products, the selected African films, one can observe that Africa is (re)presented and described through different types of texts: feature length fiction films, documentaries, short films and animation films. As a first element, this stylistic variety demonstrates that Africa does not only offer the facts and the background for television news, or documentaries about wild animals and natural paradises; rather, it also produces its own stories or technically its own audiovisual contents in a diversity of modes of communication. Parallel to this formal diversity, by simply looking, for instance, at the 39 contemporary African films selected for the three main in-competition sections at the $6^{\text {th }}$ FCAT in 2009, one can also observe that the variety of origins and themes in this official selection defines Africa across multiple characteristics. Among the twelve African feature-length fiction films in competition, eight different African nations were represented: Senegal, Tunisia, Morocco, Egypt, South Africa, Democratic Republic of Congo, Algeria and Mozambique. At the same time, a diversity of languages, ethnicities, politico-economical and socio-cultural topics was thus confronted in this programme. In the same way, the 16 in-competition African short-films and the 11 documentaries presented another wide range of African narratives, just like the rest of the non-competitive programme did. This variety in the festival film programme has always been visible in every edition, so it is easy to understand that, in comparison to the reductionist media representations of the continent, the FCAT perceives Africa and its people within its complexities and heterogeneous realities. This portrayal thus favours a more realistic image of Africa, as well as an open understanding of what African cinema means.

Although several authors have described African cinema mainly considering cinematic production from "Africa South of the Sahara" (Gugler, 2002: 3), the FCAT does not follow this partial perception of the idea of Africa and its cultural production. In fact, when one first approaches the study of African filmmaking, the relative abundance of literature about subSaharan cinema - mainly of its francophone production - might lead one to consider as African cinema only what could be better defined as Sub-Saharan Black African filmmaking. 
In this sense, several African origins, ethnicities and histories seem not to find their space in the label of "African cinema". This is the case, for example, of Northern Africa, where ethnic, socio-cultural and industrial differences with black Africa(n cinema) seem to have restricted its film production to the world of the Arab cinema. However, by looking at the programme of any FCAT edition, one seems to be reminded that the Northern African realities are as "African" as those of the sub-Saharan region. In fact, out of the 128 films programmed and shown at the $6^{\text {th }}$ FCAT, 30 of them were productions from the Magreb. Africa is thus represented within its real diversities at the FCAT and, considering African cinema as the diverse continental film production, the event celebrates Africa within its variety of aspects and accents. This fact demonstrates that the FCAT's programmers and organisers consider the label of "African cinema" in a wider, more complex and arguably objective way, interestingly close to Murphy's observation: "The category of African cinema should be used descriptively rather than prescriptively: one cannot force the cinema of an entire continent to adhere to some preordained programme" (Murphy, 2000: 247).

However, despite this complexity and diversity in the ways Africa is represented at the FCAT, some topical and stereotypical repetitions have still been observed in the programme. In fact, when analysing the 2009 in-competition selection of Spanish documentaries focusing on Africa called "Through the looking Glass" (FCAT, 2009: 133), Mhando highlighted the prevalence of a "dangerous" abundance of films that "deal with the issue of African migrants to Europe" (Mhando, 2009). Seven out of these ten selected documentaries dealt in fact with stories concerning the experiences of Africans migrating to Europe. According to Mhando, this "is a very topical issue, and making it almost one of the key subjects of a festival [...] is a danger that a festival needs to start to take stock of" (Mhando, 2009). The fact that more than half of these Spanish documentaries explored such topic can be obviously linked with the contemporary increase of African immigration in Spain and the several Spanish media misrepresentations of this phenomenon. In this sense, offering through the FCAT the possibility of an alternative representation of this burning topic seems just and necessary. Nevertheless, just as Mhando argues, such repetition of topical subjects can help to augment the already existing presuppositions and stereotypes.

It is so topical that people cannot remove from the immediacy of the other media. Because of this, we can immediately have that kind of environment in which the film fails to make an impact, because there is already a wall that is built through the other media discussions, confrontations, and sometimes over-representation of the subject of the illegal migrant. So my fear is: when there is a topic, a subject that is very topical, bringing films around that topic might be supporting the weaknesses of those representations that media are actually doing in society (Mhando, 2009).

Not only can the presence of topical issues in the programme affect the realistic representation of Africa promoted by the FCAT. African films can also carry elements which will not make justice to such image. According to the Mozambican director Pedro Pimenta, member of the jury for documentaries at the $6^{\text {th }}$ FCAT, several African filmmakers still reproduce some stereotypes in their own film production. According to Pimenta, this is both due to "an unconscious need to fulfil European expectations" and to the existence of "global stereotypes", promoted by the "hegemonic Western discourse" (Pimenta, 2009): 
Perceptions of Africa are driven by media and we know what stereotypes they imply. We also know that counter-balancing these perceptions, using different kinds of forms - not only the cultural action - is something that requires a long time. [...] Some of the films that I have seen here at the FCAT are still carrying some of these stereotypes. We can classify them as 'funny stereotypes' and I am sure they were created with the best initial intentions. [...] For example, in many films, I saw some shots, completely unframed, in which, without knowing or understanding why, we see an African statue or mask. They are introduced from a totally different discourse, as though they were there just to legitimize the "Africaness" of the story. [...] In this context, African filmmakers and producers of audiovisual contents have a great responsibility. African filmmakers demonstrate that they sometimes produce texts to fulfill European expectations about Africa and so the creators themselves fall into the simplicity of these 'funny' or exotic stereotypes. [...] These stereotypes respond both to the need for fulfilling a European expectation, but also to the hegemony of Western discourses about Africa (Pimenta, 2009).

Parallel to Pimenta's arguments and despite its plural cinematic programme, the FCAT, as a cultural and touristic event in itself, also manifests some contradictions as far as a less stereotypical and topical representation of Africa is concerned. Looking at the evolution of its so-called "parallel activities", one can realise that the FCAT has been reproducing several of those simplifications for the possible fulfilment of European (tourists') expectations. In its first editions, in fact, the MCAT used to organise several round-tables to discuss problems concerning contemporary African societies. In these spaces, several volunteering organisations and humanitarian NGOs working in Africa used to present their activities, contributing to an image of Africa as a land full of critical situations and poor people to help with European aid. At the same time, even if it does represent a very important part of different African cultures, during the most recent editions of the FCAT, workshops of African dancing and percussions have been freely offered to the festival audience. These de-contextualised workshops could also be observed as mere touristic attractions, framed within generalisations of the African artistic expressions.

Similarly, looking at the evolution of the official images that have defined the posters and informative material of the FCAT, one can observe the presence of further simplifications in the ways Africa was thought by the event ${ }^{6}$. After the minimalist cinema-inspired symbol of its first edition, the $2^{\text {nd }}$ MCAT used a photogram from Djibril Diop Mambéty's film La Petite Vendeuse de Soleil (The Little Seller of the Sun) for its poster. From the $3^{\text {rd }}$ MCAT up to the $5^{\text {th }}$ FCAT, the event adopted different cartoon-like images in which Africa was repeatedly depicted within its usual colourful stereotypes: wide savannah or lush forests and bright colourful open skies on the image background, while a feminine young black character appeared in the middle of the image with film symbols. Only for the $6^{\text {th }}$ FCAT, the event re-defined its corporate image towards a conceptual and stylish image. This poster represented the outline of the African continent with the union of words referring to the ideas of the FCAT. In it, together with the image of a black filmmaker in front of a shooting camera and the name of the event highlighted in the mosaic of words, the following terms can be read: co-operation, diversity, colour, camera, shoot, strength, multicultural, discover, action, much more, richness, traditional, contemporary, grow, film, movement, quality, international, reinvention, creativity, surpris-

6 See annex at the end of this article with the different images of the eight posters of the past editions of the MCAT and FCAT. 
ing and seventh art. As it can be clearly read, only in its $6^{\text {th }}$ edition the FCAT changed its image with very precise ideas of what representing Africa means. In a similar way, the official posters of the $7^{\text {th }}$ and $8^{\text {th }}$ FCAT have also challenged the (stereo)typical representations of Africa by using inspirational artistic images made by awarded Spanish and African artists: Spanish Blanca Orozco's African woman portrait painting for $7^{\text {th }}$ FCAT poster and Kenyan photographer Mimi Cherono Ng'ok's black and white woman pose picture for $8^{\text {th }}$ FCAT edition poster.

Each of the aforementioned parallel activities, as well as the previous posters, seem to have been produced by the FCAT as a consequence of those "unconscious global/funny stereotypes" which can fulfil the visitors' (European) expectations of Africa. In other words, even within an African film event in which "diversity and originality" are the main criteria to select African films (Berger, 2009), Africa has still been represented using colourful scenarios, exotic sounds and traditional dancing. However, with the change of corporate image at the $6^{\text {th }}$ FCAT, Africa seems to have been eventually re-represented within its diversity of signifiers and qualities.

\section{TOWARDS CONCLUSIONS... UNDERSTANDING AFRICA AT THE ENCOUNTERS OF THE FCAT}

The constant evolution, changes and improvements in the (re-)representation of both the FCAT and Al-Tarab activities can be observed as a result of the intercultural dialogues that occurred in this African film event since its creation. Just as Pimenta explained, "in order not to become another African film festival, the FCAT should not stop questioning itself" (Pimenta, 2009).

In fact, the successful development of this film event - from an amateur organisation to a professionalised NGO, demonstrates the effects of a truly attentive intercultural dialogue between Spain and Africa. In this sense, through the personal, cultural and professional encounters favoured by African cinema, the FCAT organisation has not only been able to construct a governmental policy-influencing structure, but also to make interculturalism a living practice. At the same time, with the FCAT a new influential space for the knowledge of Africa has undoubtedly emerged in Tarifa. With its wide and diverse programme, the FCAT not only promotes a more realistic representation of the continent, but it also establishes new ways of relating Africa to Spain through cinema. As a member of the $6^{\text {th }}$ FCAT jury, the Senegalese director and producer Clarence Thomas Delgado confirmed that Tarifa's "best film [...] has to be the film that best represents the link between the two continents. In this sense, awarding films at this festival means finding the film that can best fit in the guiding principle of FCAT's intentions" (Delgado, 2009). The films awarded at the FCAT are thus the embodiment of a new intercultural relationship, which will allow Spanish audiences not only to understand Africa better, but also to obtain a meaningful reflection on their own European and Spanish viewpoint. In this sense, African films at the FCAT are not mere isolated representations of a plural and heterogeneous Africa, but are (intercultural) narratives that emerge from the (intercultural) encounters of our interconnected world. Africa is hence placed in a realistic position, not as a separated and antagonist reality vis-à-vis Europe. Africa is not therefore only that conflicting and opposite other; it is not merely what is at the other side of the Strait of Gibraltar. Rather, it is a hybrid reality in which its diversity is defined by the interconnections of our globalised world. This is something that Verster perfectly explained during the discussions for the Day of Africa celebration at the $6^{\text {th }}$ FCAT: "There is no such thing as Africa separated from the world. [...] Discussions about Africa nowadays have to start looking at the continent as part of a global structure" (Verster, 2009). 
To conclude, any accurate and realistic representation of Africa cannot thus be based on simplified, topical and isolated ideas of the continent. Rather it has to be heterogeneous and hybrid, as well as critical, just as the FCAT demonstrates year after year. Just as De Valck defines the (film) festival experience as the 'ideal starting point for the development of [a cinematic and, potentially, cinephilic] taste' (De Valck, 2005: 108), the FCAT can also be observed as a promising starting point (or even active platform) for the development of a wider appreciation of African cinema and its multiple stories. In between this variety of (intercultural) narratives one can thus find the realities of Africa, as well as those multiple African voices which will favour a renovating intercultural dialogue between Western and African perspectives. In this sense, while the Spanish media representations of Africa reduce the whole continent to a Western-centric essentialist construct in which Africa functions as the quintessential representational other of Europe (Africa is black, underdeveloped and dangerous, while Europe is white, developed and safe), the FCAT offers diverse descriptions of Africa as a space of rich diversity and plurality. At the same time, with such communicative heterogeneity, the FCAT embodies a truly intercultural dialogue, which tries to overcome stereotypes and topical representations. Throughout the active implication of the FCAT in several cultural cooperation initiatives for the spread of African cinema and the improvement of its industry, the FCAT also demonstrates considering African filmmaking as a "tool" for intercultural education and human development. In here really lies the potential of this African film festival, which has established, for the first time in Spain, a solid system of mediated and real encounters for the promotion of African filmmaking and intercultural dialogues.

\section{BIBLIOGRAPHY}

AFRICANEWS.IT (2011), "African Film Festival of Tarifa Offers Movies Online" in Africanews. it, 7 February 2011, http://www.africanews.it/english/african-film-festival-of-tarifa-offersmovies-online/ [Accessed on 15 th August 2011]

ALLIANCE OF CIVILIZATIONS (2009), "Mission Statement» in United Nations Alliance of Civilizations", 2009, http://www.unaoc.org/content/view/39/187/lang,english/ [Accessed on 21 August 2009]

ANDRADE-WATKINS, Claire (2002), "African Union Film Festival. African cinema in the African century" in The Independent, 1 September 2002, http://www.aivf.org/node/44 [Accessed on 09 July 2009]

ANTHONY, David (2005), "African Film Festival in Focus" in Documentary Box, 24, 2005, pp. 19-23.

BANGRÉ, Sambolgo (1996), "African Cinema in the Tempest of Minor Festivals" in BAKARI, Imruh and Mbye B. CHAM (eds.) (1996) African Experiences of Cinema, London, BFI Publishing, pp. 157-161.

BERGER, Marion (2009), Filmed interview with author (20 May).

DE VALCK, Marijke (2005), "Drowning in Popcorn at the International Film Festival Rotterdam? The Festival as a Multiplex of Cinephilia" in Marijke DE VALCK, and Malte Hagener (eds.) (2005) Cinephilia: Movies, Love and Memory, Amsterdam, Amsterdam UP, pp. 97-109.

DELGADO, Clarence Thomas (2009), Filmed interview with author (28 May).

DIAWARA, Manthia (1994), "On Tracking World Cinema: African Cinema at Film Festivals" in Public Culture, 6.2, 1994, pp. 385-396. 
DOVEY, Lindiwe (2010), "Directors' Cut: In Defence of African Film Festivals outside Africa" in Dina lordanova with Ruby Cheung (eds.) (2010) Film Festival Yearbook 2, St. Andrews: St Andrews Film Studies, pp. 45-73.

ECRANS D'AFRIQUE, "Dossier. African cinema and Festivals" in Ecrans d'Afrique, 7, 1994, pp. 47-58.

EL PAíS.COM, "Internacional" in El País - el periódico global en español, 2011, http://www. elpais.com/internacional/ [Accessed on 10 August 2011]

FCAT, $6^{\circ}$ Festival de Cine Africano de Tarifa, del 22 al 31 de mayo 2009 [Official Catalogue of the $6^{\text {th }}$ Tarifa African Film Festival], Tarifa, Al-Tarab, 2009.

- "¿Qué es FCAT Espacio Profesional?" in Fcat.es, 2011, http://www.fcat.es/FCAT/index. php?option $=$ com content\&view $=$ category\&layout=blog\&id $=59 \& \mid$ temid $=55$ [Accessed on $15^{\text {th }}$ August 2011]

GALÁN FAJARDO, Elena (2006), "La representación de los inmigrantes en la ficción televisiva en España. Propuesta para un análisis de contenido. El Comisario y Hospital Central." in Revista Latina de Comunicación Social, 61, 2006 [Accessed online on 17 July 2009 from http://www.ull.es/publicaciones/latina/200608galan.htm]

GUGLER, Josef (2002), African film: re-imagining a continent, Oxford, James Currey.

HELSBY, Wendy et al (2005), Understanding representation, London, BFI Pub.

KEITA, Mama (2005), Notes of interview with author (25 May).

MAEC [Ministerio de Asuntos Exteriores y de Cooperación] ed., Plan África 2006-2008. Madrid, Milegraf, 2006

- Plan África 2009-2012. Madrid, s.n., 2009, http://www.maec.es/es/Home/Documents/ PLAN\%2520AFRICA\%25202009-2012 web.pdf [Accessed on 22 August 2009]

MAHNDO, Martin (2009), Filmed interview with author (26 May).

MCAT, I Muestra de Cine Africano de Tarifa, dossier oficial [1 ${ }^{\text {st }}$ MCAT Official dossier], Tarifa, Al-Tarab, 2004.

MURPHY, David (2000), "Africans Filming Africa", Journal of African Cultural Studies, 13.2, 2000, pp. 239-249.

PIMENTA, Pedro (2009), Filmed interview with author (26 May).

SENDÍN GUTIÉRREz, José Carlos (2006), Problemas asociados a la construcción del africano en los medios de comunicación en España: Análisis del tratamiento informativo de la crisis de Reuanda en Televisión Española [Doctorate thesis directed by Dr. D. Ricardo Pérez-Amat García], Madrid, Universidad Rey Juan Carlos.

SISSAKO, Abderrahmane (2009), Filmed interview with author (30 May).

THACKAWAY, Melissa (2003), Africa Shoots Back. Alternative Perspectives in Sub-Saharan Francophone African Film, Oxford, James Currey.

VÁZQUEZ AGUADO, Octavio (1999), "Negro sobre blanco: inmigrantes, estereotipos y medios de comunicación", Comunicar, 12. 60, 1999, pp. 55-60.

VERSTER, François (2009), Filmed interview with author (25 May).

WAINAINA, Binyavanga (2005), "How to Write about Africa", Granta, 92, Winter, 2005, pp. 91-95.

\section{FILMOGRAPHY}

La petite vendeuse de soleil, Directed by Djibril Diop Mambéty (Senegal, 45'), 1998

Quaderns, 7 (2011), pp. 79-92 
ANNEX:
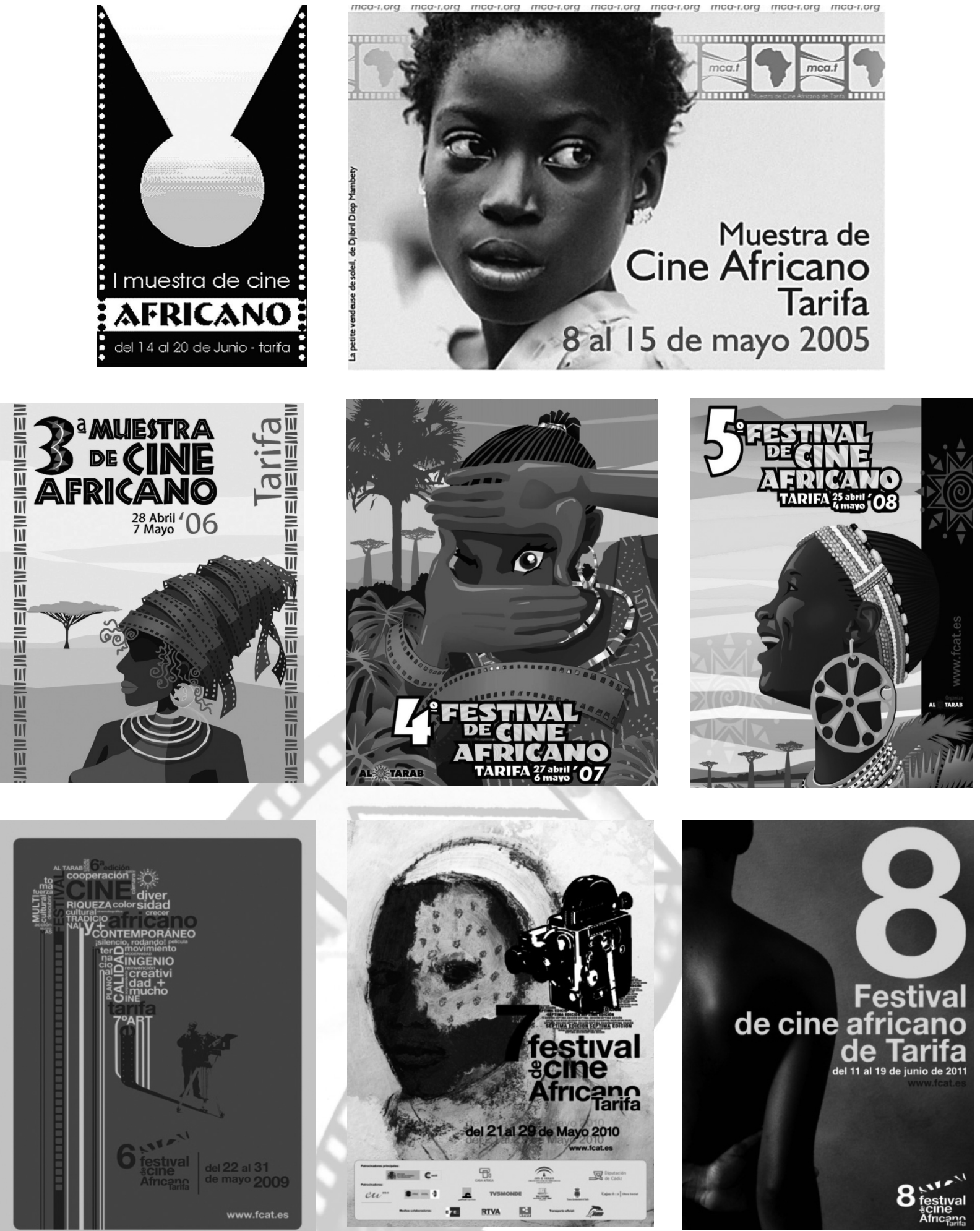

From left to right, from the upper image to the lower one; these eight images show the evolution of the posters of the past editions of the MCAT and FCAT.

(C)All the images are a courtesy and property of Al-Tarab. 